International Journal of Advanced Chemistry, $2(1)(2014) 44-48$
International Journal of Advanced Chemistry
Journal home page: $\begin{gathered}\text { www.sciencepubco.com/index.php/IJAC } \\ \text { doi: } 10.14419 / \text { ijac.v2il.1863 } \\ \text { Research Paper }\end{gathered}$

\title{
Evaluation of removal efficiency of cu (II) ion by activated carbon prepared from Nirgudi, Mudra and Gliricidia Sipium leaves from their aqueous solution
}

\author{
M. Mustaqeem M. Sharif BAGWAN ${ }^{1 *}$, P. R. PATIL ${ }^{2}$ \\ ${ }^{I}$ Department of Chemistry, IES' H. J. Thim College of Arts and Science, Jalgaon \\ ${ }^{2}$ School of Environmental and Earth Sciences,North Maharashtra University, Jalgaon \\ *Corresponding author E-mail: bagwanms@ rediffmail.com
}

\begin{abstract}
Present study deals with the removal of copper ions from aqueous solution by using activated carbon of natural leaves like Nirgudi (NAC), Mudra (MAC) and Gliricidia Sipium (GAC) leaves which is highly efficient, ecofriendly and locally available adsorbents. A series of experiments were conducted in a batch system to evaluate the effect of system variables. The effect of contact time, $\mathrm{pH}$ and the initial concentration of copper (II) solution were considered. The results show that the contact time 105 minutes for all adsorbent are sufficient to fit the equilibrium. The optimal adsorption $\mathrm{pH}$ for the adsorption of copper (II) ions is 7 for NAC, MAC and 8 for GAC adsorbents. The maximal quantities adsorbed by every adsorbent were 98.63 for NAC, 98.61 for MAC and 98.46 for GAC. Two isotherms models amongst which are Langmuir and Freundlich have been applied to the experimental data. The value of separation factor RL was found to be $0.01847,0.02506$ and 0.04477 for NAC, MAC and GAC respectively suggesting the isotherm to be favorable at the concentration studied. The Langmuir model best described the adsorption of copper (II) ions in aqueous solution by the selected adsorbents.
\end{abstract}

Keywords: Adsorption isotherms, gliricidia cipium, mudra and, nirgudi.

\section{Introduction}

Heavy metal ions are highly toxic for animals and human beings (Ansari et al. 2006). Heavy metal contaminates the environment and is a widespread problem (Ansari 2006). Toxic heavy metals in the aquatic ecosystem raise human health risks and cause harmful effect to living organism in water and also to the consumer of them (El-said et al. 2010). Among the heavy metal like cadmium, cobalt, zinc, copper, and iron ignition beyond permissible quantities causes psychological disorder in human beings (Prabakarani et al. 2011). The World Health Organization in 2006 recommended $2.0 \mathrm{mg} / \mathrm{L}$ as the maximum acceptable concentration of copper in drinking water. In human copper toxicity causes itching and dermatization, due to their toxicity, accumulation in food chain and keratinization of the hands and soles of feet (Banerjee et al. 2012). The removal of heavy metals from waste water has recently become the subject of considerable interest (Krishna et al. 2011). Therefore there is a growing need for the development of new, innovative and cost effective methods and the removal of metal (Sayeda et al. 2010).

A number of techniques used for the removal of metal ions from aqueous solutions have been reported mainly reduction, electrochemical precipitation, evaporation, solvent extraction, ion exchange, electrolysis, reverse osmosis, chemical precipitation are expensive and non-environmental friendly, as compared to adsorption (Muthusamy et al. 2012). Adsorption process is considered better as compared to other methods, because of convenience, easy operation and simplicity of design (Bhatanagar et al. 2006).
Activated carbon (AC) is a generic term for a family of highly carbonaceous materials none of which can be characterized by a structural formula (Verla et al, 2012). Activated carbon is amorphous solid adsorbent that can be produced form almost all carbon rich materials there are various carbon rich materials used as metal ion adsorbent (Nwabanne et al. 2012). Several adsorbents, such as dyed Senna uniflorora leaves (Nalini et al. 2013), Teak leaves (Goswami et al. 2013), Soybean hulls (Doglas et al. 2006), Cement kiln dust (Waly et al. 2010), Sugar beet pulp (Ozer et al. 2005), Sugar cane bagasse (Patil et al. 2010), , polyaniline coated saw dust (Liu et al. 2012), Hebba clay (Shama et al. 2010), Henna leaves (Shanti et al. 2013), Waste tire rubber ash (Mausavi et al. 2010), Decanter cake (Dewayanto et al. 2010), Coconut bagasse (Sousa Neto et al.2011), Chestnut shell,( Yao et al. 2010) Synthetic Geo-thite (Mertain et al. 2013), Zeolite $\mathrm{NaX}$ (Pandey et al. 2009), coconut pollen, (Agini et al. 2007) Mango leaf (Sethu et al. 2010) and Sorel's cement (Awwad et al. 2005).

The aim of this work is to study the removal of $\mathrm{Cu}$ (II) metal ions by Activated Carbon Prepared from Nirgudi, Mudra and Gliricidia Sipium leaves from synthetic waste water and to offer this adsorbent as local replacement for existing commercial adsorbent materials.

\section{Experimental}

\subsection{Materials}

The leaves of Nirgudi, Mudra and Gliricidia Cipium were collected from local field of Jalgaon District. These waste materials were 
washed with water, dried in sunlight, then $60{ }^{\circ} \mathrm{C}$ for $24 \mathrm{~h}$ in hot air oven. The dried material was subjected for acid treatment (ratio $1: 1)$ and kept at room temperature overnight, then screened through mesh sieve with different particle size range A) 500-850 micron B) $180-500$ micron C) $45-180$ micron and stored in a tight lid container for further studies.

\subsection{Preparation of activated carbon from adsorbent}

Carbon was prepared by treating air dried adsorbent with sulphuric acid in a weight ration 1:1 for $24 \mathrm{~h}$. the resulting black product was kept in an oven maintained at $500{ }^{0} \mathrm{C}$ for $12 \mathrm{~h}$ followed by washing with $\mathrm{NaHCO}_{3}$ and water until free from excess acid, the $\mathrm{pH}$ of washing becomes 7.0 and dried at $150 \pm 5^{0} \mathrm{C}$ to obtained sulphuric acid treated activated carbon of Nirgudi, Mudra and Gliricidia Cipium and its physical properties were analyzed by usual standard methodologies.

\subsection{Preparation of cu (II) solution}

The stock solution of $\mathrm{Cu}$ (II) ion was prepared by dissolving $0.3929 \mathrm{gm}$ of $\mathrm{CuSO}_{4} .5 \mathrm{H}_{2} \mathrm{O}$ in $1000 \mathrm{ml}$ volumetric flask and mace up to the mark with double distilled water. All the required working solutions were prepared by diluting the stock solution with double distilled water. Batch adsorption studies were performed at room temperature.

\subsection{Experimental methods and measurement}

The adsorption experiments were carried out by agitating the carbon with $50.75 .100 \mathrm{mg} / \mathrm{l}$ metal ion solution of desired concentration at $\mathrm{pH} 7.0$ and at room temperature in a mechanical Shaker $(120 \mathrm{rpm})$ after a defined time interval, samples were withdrawn from the shaker, filtered by Whatman filter paper No. 1 and the supernant solution was analyzed for $\mathrm{Cu}$ (II) ion concentration using an Atomic Absorption Spectrometer (Thermo scientific Sseries AA Spectrometer) at $324.8 \mathrm{~nm}$.

\section{Results and discussion}

The four natural easily available adsorbents were selected from local area. The Table 1 shows selected adsorbents from natural waste.

Table 1: Selected adsorbents from natural waste:

\begin{tabular}{llll}
\hline Sr.No. & Adsorbent Name & Botanical name & Abbreviation \\
\hline 1 & Nirgudi & Vitex Nigundo & NAC \\
2 & Mudra & Abutulan Indicum & MAC \\
3 & Gliricidia & Gliricidia Sipium & GAC \\
\hline
\end{tabular}

\subsection{Characteristics of the adsorbent}

The physico-chemical properties of the prepared activated carbon were determined by standard methods (Table 2 ).

Table 2: Characteristics of adsorbents

\begin{tabular}{lllll}
\hline Sr No & Properties & NAC & MAC & GAC \\
\hline 1 & Density $\left(\mathrm{g} / \mathrm{cm}^{3}\right)$ & 0.4408 & 0.2092 & 0.3692 \\
2 & pH & 6.8 & 7.1 & 6.8 \\
3 & Moisture content $(\%)$ & 0.8 & 10.2 & 12.8 \\
4 & Ash Content $(\%)$ & 6.4 & 10 & 11.7 \\
\hline
\end{tabular}

\subsection{Effect of contact time}

Figure 1 showed the percentage removal of the $\mathrm{Cu}$ (II) metal ions by the NAC, MAC and GAC as adsorbent. The effect of contact time was studied in the range of $15,30,45,60,75,90$, and 120 min. It reveals that the $\mathrm{Cu}$ (II) metal ion present in the synthetic wastewater, there was a progression in the percentage removal of metal ion present in the synthetic wastewater with time on all selected adsorbents. The results also showed that, the adsorption was fast at initial stage of contact period and after that near the equilibrium it became slower. Adsorptions reach equilibrium within $120 \mathrm{~min}$ for all selected adsorbent. From the result of the adsorption experiment $\mathrm{Cu}^{2+}$ ions had the highest percent removal of 98.63 at the end of 105 min by the NAC, followed by MAC and GAC with 98.61 and 98.46 respectively. These results are important, as equilibrium time is one of the important parameters in adsorption, and the time consumed for industrial wastewater disposal should be considered. The fast metal uptake by the adsorbent may be attributed to their highly porous and mesh structure, which provide a large surface area for the adsorption of $\mathrm{Cu}$ (II) onto the binding sites (Pankaj P et al. 2009). Thus for subsequent experiments, an equilibrium time of 120 minutes was chosen for the sake of convenience.

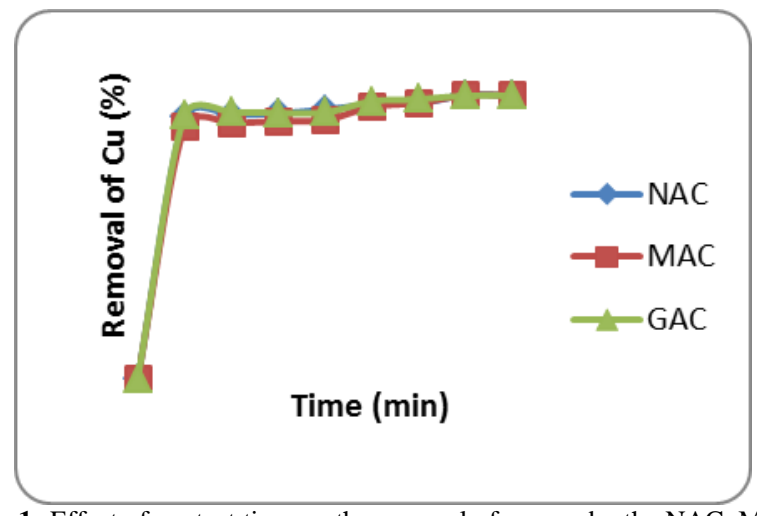

Fig. 1: Effect of contact time on the removal of copper by the NAC, MAC

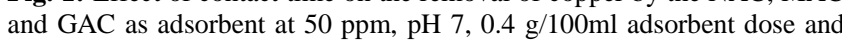
particle size 45-180 micron.

\subsection{Effect of particle size}

Surface area of the adsorbent is an important parameter for adsorption. Exposure of adsorbent sites for solid metal ion interaction is high if the surface area of adsorbent is high ${ }^{12}$. Hence to study this parameter batch adsorption studies were done by using three different particle sizes of NAC, MAC and GAC such as A= $500-850, \mathrm{~B}=180-500, \mathrm{C}=45-180$ micron. The relationship between the size of the particles of the adsorbent and the copper metal ion removal percentage is illustrated in Fig 2.

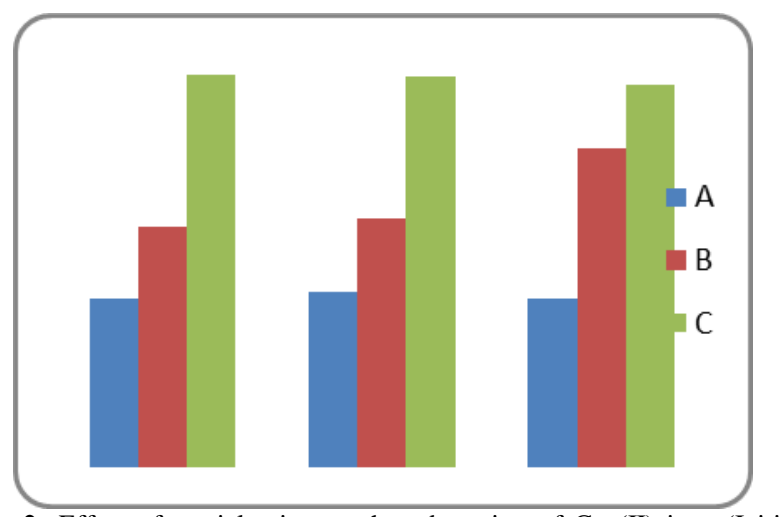

Fig. 2: Effect of particle size on the adsorption of $\mathrm{Cu}$ (II) ions (Initial concentration: $50 \mathrm{mg} / 1$, contact time: $120 \mathrm{~min}, \mathrm{pH}$ : 7.0, temperature: 301 $\pm 1 \mathrm{~K}$, adsorbent dosage: $0.4 \mathrm{~g} / 100 \mathrm{ml}$, Particle size: $\mathrm{A}=500-850, \mathrm{~B}=180$ 500, $\mathrm{C}=45-180$ micron).

Fig 2 indicates that the percentage $\mathrm{Cu}$ (II) ion removal has increased with the decrease in particle size. As the particle size is smaller, the surface area per unit weight of adsorbent is larger and consequently the higher percentage of metal removal is noted ${ }^{5}$. The maximum percentage of $\mathrm{Cu}$ (II) ions were removed by taking the adsorbent size of 45-180 micron. Hence for the entire study 
NAC, MAC and GAC of 45-180 micron were used in order to produce effective adsorption process.

\subsection{Effect of $\mathbf{p H}$}

The $\mathrm{pH}$ is an important parameter for adsorption of metal ions from aqueous solution because its affects the solubility of metal ions. For this the role of hydrogen ion concentration was examined at different $\mathrm{pH}$. The effect of initial $\mathrm{pH}$ on the extent of removal of $\mathrm{Cu}$ (II) ions by adsorption on NAC, MAC and GAC at $28^{\circ} \mathrm{C}$ is given in Fig.3. The adsorptions of $\mathrm{Cu}$ (II) ions on the adsorbents are found to be highly $\mathrm{pH}$ dependent. As $\mathrm{pH}$ increases, the extent of removal increases, reaches a maximum value and then decreases further increased up to optimum $\mathrm{pH}$. The optimum $\mathrm{pH}$ for removal of $\mathrm{Cu}^{2+}$ ions is fixed as 7.0 for NAC and MAC The optimum $\mathrm{pH}$ for removal of $\mathrm{Cu}^{2+}$ ions is 8 for $\mathrm{GAC}^{5}$. The neutral $\mathrm{pH}$ is found to be favorable. This suggests the Copper adsorption was very low at $\mathrm{pH}<2$ and at $\mathrm{pH}>8.0$, metal removal was due to precipitation caused when $\mathrm{OH}^{-}$ions formed complex with copper (Mamatha et al. 2013).

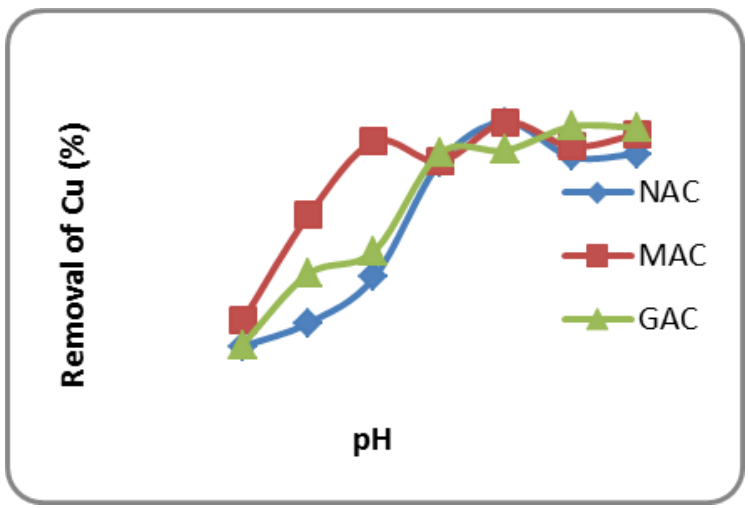

Fig. 3: Effect of $\mathrm{pH}$ on copper adsorption by NAC, MAC and GAC at an initial concentration of $50 \mathrm{ppm}, 120 \mathrm{~min}$, and $0.4 \mathrm{~g} / 100 \mathrm{ml}$ adsorbent dose

\subsection{Effect of initial concentration of cu (II)}

In batch adsorption processes, the initial metal ion concentration of metal ions in the solution plays a key role as a driving force to overcome the mass transfer resistance between the solution and solid phase. The effect of initial metal ion concentration ranging from $50-100 \mathrm{mg} / 1 \mathrm{on}$ NAC, MAC and GAC was studied by taking different concentrations of $\mathrm{Cu}$ (II) solutions at $\mathrm{pH} 7$, while keeping the dosage of the adsorbent $0.4 \mathrm{~g} / 100 \mathrm{ml}$ constant and temperature at $28{ }^{\circ} \mathrm{C}$. The results are tabulated in Table 3 .

Table 3: Effect of initial metal concentration on the adsorption of $\mathrm{Cu}$ (II) ion by NAC, MAC and GAC (contact time $=120 \mathrm{~min}, \mathrm{pH} 7.0$, temperature $=28{ }^{\circ} \mathrm{C}$ and adsorbent dosage $=0.4 \mathrm{~g} / 100 \mathrm{ml}, \mathrm{V}=100 \mathrm{ml}$, Time: $120 \mathrm{mins}$ $\mathrm{W}=400 \mathrm{mg}$ )

\begin{tabular}{llllllllll}
\hline $\mathrm{Ci}$ & $\mathrm{Ce}$ & & \multicolumn{3}{c}{ Qe } & \multicolumn{4}{c}{ \% of Cu removed } \\
\hline & NAC & MAC & GAC & NAC & MAC & GAC & NAC & MAC & GAC \\
50 & 0.68 & 0.69 & 0.76 & 12.32 & 12.32 & 12.30 & 98.63 & 98.61 & 98.46 \\
75 & 1.70 & 1.44 & 1.09 & 18.32 & 18.38 & 18.47 & 97.73 & 98.07 & 98.54 \\
100 & 4.51 & 2.90 & 2.41 & 23.87 & 24.27 & 24.39 & 95.48 & 97.09 & 97.58 \\
\hline
\end{tabular}

It is indicated from the Table 3 that the percent adsorption decreases with the increase of initial metal ion concentration. As a result of the above observations, it is indicated that the adsorption process of $\mathrm{Cu}$ (II) ions on NAC, MAC and GAC has to be dependent on concentration of the metal ion solution up to some extent.

\subsection{Adsorption isotherms}

The adsorption data was analyzed with the help of the Freundlich and Langmuir isotherms:

The Langmuir isotherm is represented by the following equation $(\mathrm{Ce} / \mathrm{qe})=(1 / \mathrm{b} \mathrm{Q} 0)+(\mathrm{Ce} / \mathrm{Q} 0)$
Where,

qe $=$ amount of dye adsorbed at equilibrium $(\mathrm{mg} / \mathrm{g})$,

$\mathrm{Ce}=$ equilibrium concentration of dye $(\mathrm{mg} / \mathrm{L})$,

$\mathrm{Q}_{0}=$ Langmuir Constant related to adsorption efficiency $(\mathrm{mg} / \mathrm{g})$ and

$\mathrm{b}=$ Langmuir Constant related to energy of adsorption $(\mathrm{L} / \mathrm{mg})$ [4].

The linear plots of Ce/qe versus Ce suggest the applicability of the Langmuir isotherms (Figure 4-6) NAC, MAC and GAC respectively. The values of $\mathrm{Qo}$ and $\mathrm{b}$ were determined from the slope and intercept of the plots (Table 4). The high value of correlation coefficient $r^{2}$ from Table 4 indicates that the adsorption of $\mathrm{Cu}$ (II) ion by NAC, MAC and GAC follows Langmuir isotherm model. The Table 4 also gives information about the adsorption capacity (Q0) and energy of adsorption b of NAC, MAC and GAC adsorbents.

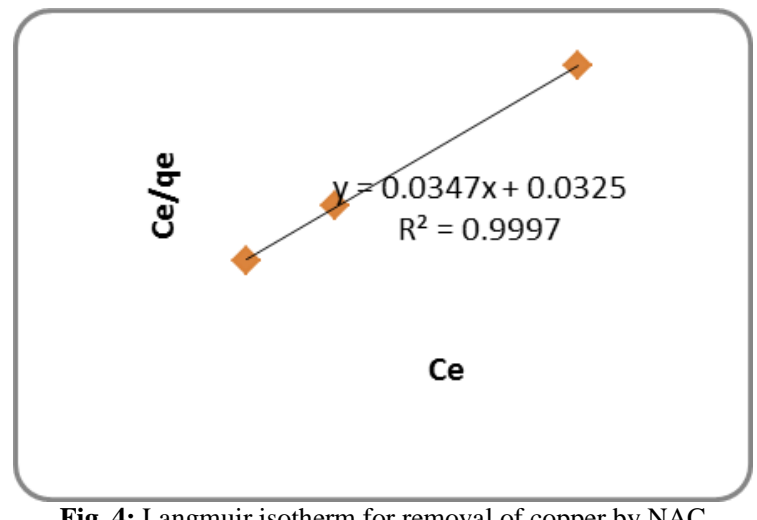

Fig. 4: Langmuir isotherm for removal of copper by NAC

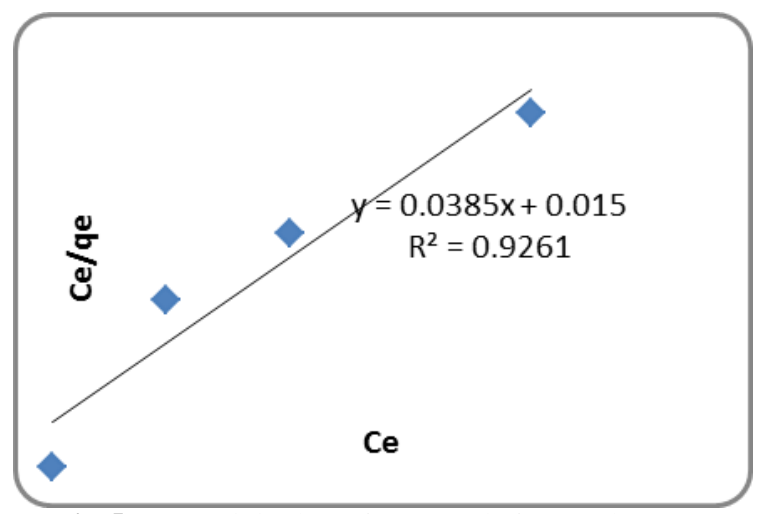

Fig. 5: Langmuir isotherm for removal of copper by MAC

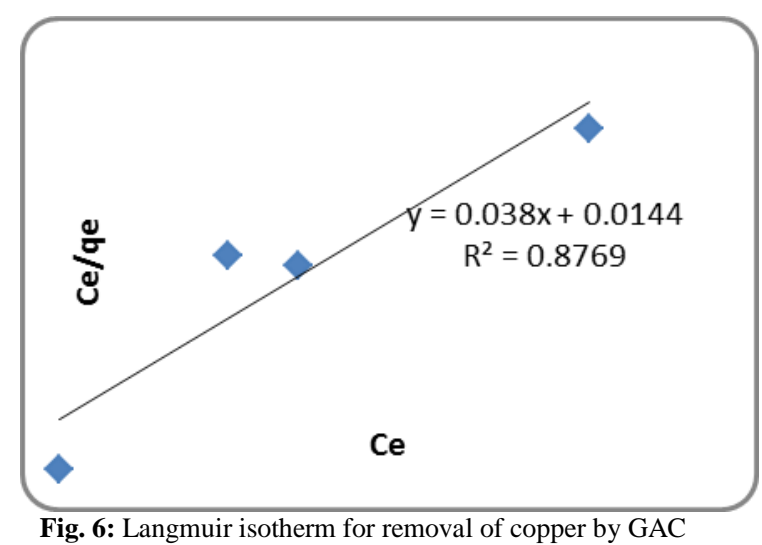

To confirm favorability of the adsorption process, the separation factor $\left(\mathrm{R}_{\mathrm{L}}\right)$ is calculated and presented in Table 4 . The values are found to be between 0 and 1 and confirmed that the ongoing adsorption process is favorable.

$\mathrm{R}_{\mathrm{L}}=1 /(1+\mathrm{bCi})$

Here, $\mathrm{b}$ is the Langmuir constant and $\mathrm{Ci}$ is the initial concentration of $\mathrm{Cu}$ (II). 
The Freundlich isotherm is also employed for the adsorption of $\mathrm{Cu}$ (II) on the adsorbent. The Freundlich isotherm is represented by the following equation

$\log \mathrm{qe}=\log \mathrm{kf}+(1 / \mathrm{n}) \log \mathrm{ce}$

Here, qe is the amount of $\mathrm{Cu}$ (II) adsorbed (mg/l), ce is the equilibrium concentration of $\mathrm{Cu}$ (II) in the solution (mg/l) and $\mathrm{kf}$ and $\mathrm{n}$ are constant incorporating all factors affecting the adsorption capacity and intensity of adsorption, respectively. The plot of log qe versus log ce (Fig. 7-9) suggest that applicability of Freundlich isotherm for NAC, MAC and GAC. The values of $\mathrm{kf}$ and $\mathrm{n}$ were determined from the slope and intercept of the plots (Table 4).

Table 4: Langmuir and Freunlich parameters of adsorption isotherms

\begin{tabular}{llllllll}
\hline $\begin{array}{l}\text { adsor- } \\
\text { bents }\end{array}$ & \multicolumn{2}{l}{$\begin{array}{l}\text { Langmuir isotherm } \\
\text { results }\end{array}$} & & \multicolumn{5}{c}{$\begin{array}{l}\text { Freundlich is } \\
\text { otherm results }\end{array}$} \\
\hline \multirow{3}{*}{ NAC } & Qo & $\mathrm{b}$ & $\mathrm{r}^{2}$ & $\mathrm{R}_{\mathrm{L}}$ & $\mathrm{Kf}$ & $1 / \mathrm{n}$ & $\mathrm{r}^{2}$ \\
& 29.4 & 1.062 & 0.99 & 0.0184 & 1.16 & 0.34 & 0.98 \\
MAC & 1 & 5 & 9 & 7 & 0 & 8 & 2 \\
& 35.7 & 0.777 & 0.99 & 0.0250 & 1.17 & 0.47 & 0.99 \\
GAC & 1 & 8 & 9 & 6 & 3 & 3 & 2 \\
& 61.6 & 0.426 & 0.93 & 0.0447 & 1.19 & 0.55 & 0.89 \\
\hline
\end{tabular}

From the Table (4), the Freundlich constant, 1/n denoting the intensity of adsorption indicates a favorable adsorption since $1 / \mathrm{n}<$ 1.The adsorptions of $\mathrm{Cu}$ (II) ions onto NAC, MAC and GAC studied had been more favorable. The same result of $R_{L}$ that is $(0<R L$ $<1$ ) for the adsorption of copper was investigated by Akai $\mathrm{M}$ Awwad (Awwad et al. 2012). The adsorption capacity (kf) obtained for different adsorbents has been comparable, among them GAC shows highest value of adsorption capacity.

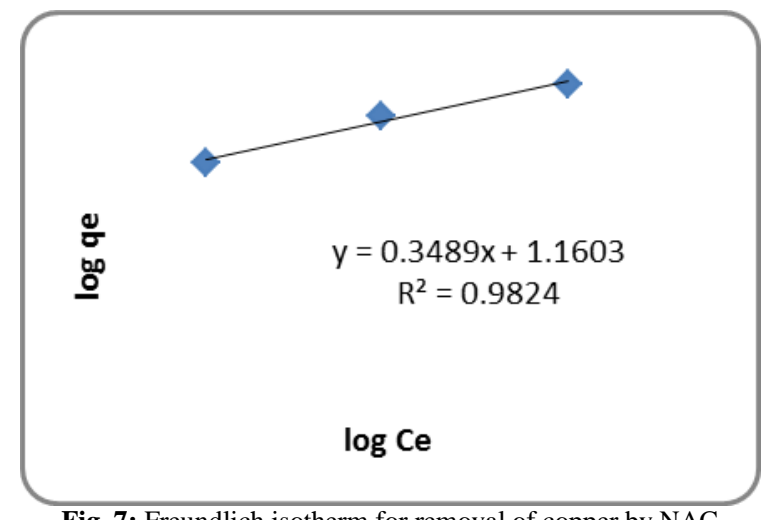

Fig. 7: Freundlich isotherm for removal of copper by NAC

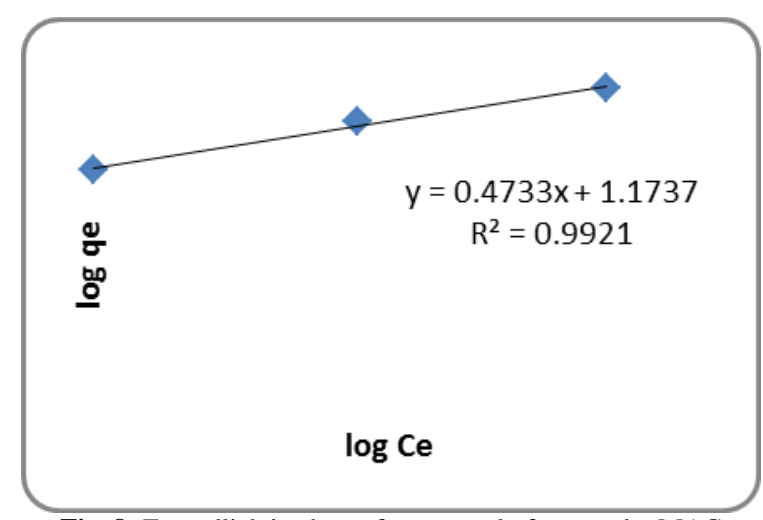

Fig. 8: Freundlich isotherm for removal of copper by MAC

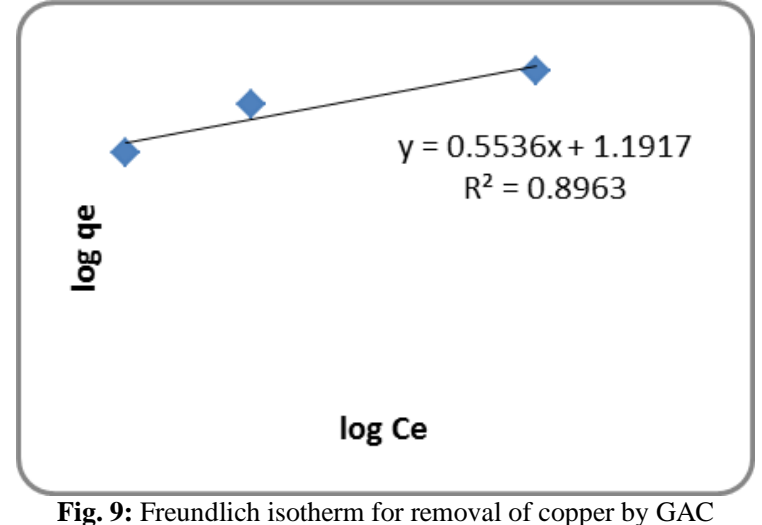

\section{Conclusion}

This work clearly indicates the potential of using NAC, MAC and $\mathrm{GAC}$ as an excellent adsorbents for the removal of $\mathrm{Cu}$ (II) ions from aqueous solutions. The amount of $\mathrm{Cu}$ (II) ions adsorbed onto the NAC, MAC and GAC increased with an increase in $\mathrm{pH}$. The optimum $\mathrm{pH}$ was found as $\mathrm{pH} 7$ for the removal of $\mathrm{Cu}$ (II) ions by NAC and MAC while $\mathrm{pH}=8$ for except $\mathrm{GAC}(\mathrm{pH}=8)$. The NAC, MAC and GAC of particle size 45-180 micron were identified to bring about maximum adsorption percentage of $\mathrm{Cu}$ (II) ions. The equilibrium data was analyzed for the Langmuir and Freundlich isotherm model. Among these two isotherms, Langmuir isotherm fitted well with the experimental data than Freundlich isotherm. This confirms the monolayer adsorption process. Taking into consideration of the above results, it can be concluded that the NAC, $\mathrm{MAC}$ and GAC were a suitable adsorbents for the removal of $\mathrm{Cu}$ (II) ions from aqueous solution in terms of low cost, natural and abundant availability.

\section{Acknowledgement}

The authors gratefully acknowledge the laboratory and chemically support of iqra education society and north maharash-tra University, jalgaon. The authors are also thankful to umesh fegde, dr. tanvir khan for the identification of plants.

\section{References}

[1] Agiri G. O., Akaranta O. and Ajayl I. O. (2007), Studies on died coconut pollens for removal of $\mathrm{Cu}$ (II) and $\mathrm{Zn}$ (II) from aqueous solution African Journal of Biotechnology 6, 929-932.

[2] Ansari R and Raofie F (2006), Removal of Lead ion from aqueous solution using sawdust coated by polyanniline. E-Journal of Chemistry 3, 49-59.

[3] Ansari R (2006), Application of polyaniline and its composites for adsorption/Recovery of Chromium (VI) from aqueous solutions. Acta Chimica Solvsis 53, 88-94.

[4] Awwad AM and Salem NM (2012), Biosorption of copper (II) and lead (II) from aqueous solution by modified loquat leaves. Journal of Chemical Engineering and Materials Science, 3, 7-17.

[5] Awwad NS and Daifullah AAM (2005), Preconcentration of U (VI) from aqueous solution after sorption using Sorel's cement in dynamic mode. Journal of Radioanalytical and Nuclear Chemistry, 264, 623628.

[6] Banerjee K, Ramesh ST, Himathi RG, Nidheesh PV and Bharathi KS (2012), Iranica Journal of Energy and Environment 3, 143-156.

[7] Bhatanagar A and Minocha AK (2006), Conventional and nonconventional adsorbents for the removal of pollutants from water- A review. Indian Journal of Chemical Technology 13,203-217.

[8] Doglas S, Pongamphai S, Lerdtrilluck S, Polchai S, Kaewchana A and Osataworanum B (2006), Adsorption of $\mathrm{Cu}$ (II) ion from aqueous solution using soybean hulls. "Sustanable Energy and Environment", $2^{\text {nd }}$ Int. Conf., 2006, Bankok, Thailand.

[9] El-Said AG, Badaway NA and El Pasir AA (2010), Comparison of synthetic and natural adsorbents for sorption of $\mathrm{Ni}$ (II) ions from aqueous solution. Journal of Nature and Science 8, 86-94. 
[10]Goswami AK, Kulkarni SJ, Dharamadhikari SK and Phutke M (2013), Adsorption of $\mathrm{Cu}$ (II) ion from syuthetic waste water by teak leaves. International Journal of Science, Engineering and Technology research 2, 1356-1359.

[11]Krishna RH and Swamy AVVS (2011), Studies on nthe removal of Ni (II) from aqueous solution using powder of Mosambi fruit peelings as a low cost sorbent. Chemical Sciences Journal 31, 1-13.

[12] Liu D and Sun D (2012), Modeling adsorption of $\mathrm{Cu}$ (II) using polyaniline coated saw dust in a fixed bed column. Environment Engineering Science 29, 461-465.

[13] Mamatha M, Aravinda HB, .Puttaiah ET and Manjappa S (2013), Factor and kinetic involved in adsorption of $\mathrm{Cu}$ (II) from aqueous and waste water onto pongamia pinnata. International Journal of Innovative Research in Science, Engineering and Technology, 2, 1091-1098.

[14]Mausavi HZ, Abdurrahman $\mathrm{H}$ and Jahed V (2010), Removal of $\mathrm{Cu}$ (II) from wastewater by waste tire rubber ash Journal of Siberian Chemical Society 75, 845-852.

[15]Merlain TG, Julinus Nsami ND and Mbadcam KJ (2013), Adsorption of Copper (II) Ions from Aqueous Solution onto Synthetic Goethite and Two Naturally Available Red Soils from Yaoundé -Cameroon British Biotechnology Journal 3, 221-235.

[16]Muthusamy P., Murugan S. and Manothi S (2012), Removal of Nickel ion from industrial waste water using Maize cob. ISCA Journal of Biological Sciences, 1, 7-11.

[17]Nalini T and Nagarajan P (2013), the removal of copper from aqueous solution using senna uniflora. International Journal of Chemical and Technical research 5, 1854-1860.

[18] Nugroho D, Husin MH, Yong LK, and Nordin MR (2010), waste to valuable by product: kinetic and thermodynamic studies of $\mathrm{Cd}, \mathrm{Cu}$ and $\mathrm{Pb}$ ion removal by decanter cake. Journal of Engineerimg and Tech nology 1, 85-98.

[19]Nwabanne JT and Igbokwe PK (2012), Comparative study of Lead (II) removal from aqueous solution using different adsorbents. International Journal of Engineering Research and Applications 2, 18301838.

[20]Ozer A and Tumen F (2005) $\mathrm{Cu}$ (II) adsorption from aqueous solutions on sugar beet pulpcarbon the European Journal of Mineral Procecing and Environment Protection 5, 26-34.

[21]Pankaj P, Sambi SS, Shama SK and Singh S, Batch (2009) Adsorption Studies for the Removal of $\mathrm{Cu}$ (II) Ions by ZeoliteNaX from Aqueous Stream. "Eng and Comp Sci" World Congress, San Fracisco, USA.

[22]Patil KP, Patil VS, Patil N and Motiraga V (2012), Adsorption of Zinc and copper ions from waste water by using soyabean hulls and sugarcane bagasse as adsorbents. International Journal of Scientific research and Review 1, 13-23.

[23]Prabakarani R, Arivoli S, Hema M and Kamatchi C (2011), Removal of $\mathrm{Cu}$ (II) ion from aqueous solution by low cost activated carbon from thespesia populnea bark. Journal of Chemical and Pharmaceutical Research 3, 532-543.

[24] Sayeda MI (2010), Removal of Copper and Chromium ion by using hydrophilic finished textile febrics. Fibers and Textile in Estern Europ $18,99-104$

[25] Sethu VS, Goey KS, Iffah FR, Khoo CM and Andresen AM, Adsorption characteristic of $\mathrm{Cu}$ (II) ion in aqueous solution using mangifera indica leaf bisorbents. Journal of Environment, Research and Development 5, 262-278.

[26]Shama SA and Gad MA (2010), removal of heavy metals from aqueous solution by using Hebba clay and activated carbon. Portugalial electrochemical Acta 28, 231-239.

[27]Shanti T and Selvarajan VM (2013), Removal of Chromium (VI) and copper (II) ion from aqueous solution by crbon prepared from henna leaves. Journal of Chemistry 1, 1-6.

[28] Sousa Neto VO, Oliveira AG, Raimundo N. P, Marcos A. A. Silva, Freire PC, Keukeleire DD and Nascimento RF(2011), Use of coconut bagasse as alternative adsorbent for the separation of copper (II) from aqueous solution: Isotherm, Kinetic and thermodynamic studies. Bio Resources 6, 3376-3395.

[29]Verla AW, Horsfall M, Verla EN, Spiff AI and Ekpete OA (2012), Preparation and characterization of activated carbon from fluted pumpkin seed shell. Asian Journal of Natural and Applied Sciences 1 39-50.

[30] Waly TA, Dakroury AM, El-Sayyed GO and Salam SE (2010), Assessment Removal of Heavy Metals Ions from Wastewater by Cement Kiln Dust (CKD). Journal of American Science 6, 910-917.

[31] Yao ZY, Qi JH and Wong LH (2010), Equilibrium, kinetic and thermodynamic studies on the biosorption of $\mathrm{Cu}$ (II) onto chestnut shell Journal of Hazardous Mater174, 137-143. 